\title{
1 High-yield purification of commercial lactulose syrup
}

2 Cristina Julio-Gonzalez, Oswaldo Hernández-Hernández, F. Javier Moreno*, Agustín

3 Olano, Nieves Corzo

4 Department of Bioactivity and Food Analysis

5 Institute of Food Science Research, CIAL, (CSIC-UAM) CEI (UAM + CSIC)

6 C/ Nicolás Cabrera, 9, E-28049 Madrid (Spain)

7

8

9 *Author to whom correspondence should be addressed:

10 E-mail: javier.moreno@csic.es

$11 \quad$ Tel: +34 910017948

12

13

14 


\section{ABSTRACT}

16 A simple process for purifying lactulose in commercial lactulose syrups was developed.

17 The objective was to establish a selective enzymatic hydrolysis of lactose and epilactose 18 and further removal of monosaccharides by activated charcoal and water/ethanol

19 solutions. Four commercial $\beta$-galactosidases from different microorganisms were tested 20 obtaining significant differences in their activities towards the three disaccharides present 21 in the lactulose syrup. $\beta$-galactosidases from Bacillus circulans (Biolactasa ${ }^{\circledR}$ NTL $^{*} 2$ ) and 22 Bifidobacterium bifidum (Saphera ${ }^{\circledR} 2600$ L) showed a reduced enzymatic activity towards 23 lactulose and a high enzymatic activity towards lactose. These two enzymes were chosen 24 to optimize the lactose hydrolysis methodology using Response Surface Methodology 25 (RSM). Once chosen the optimum enzymatic conditions to selectively hydrolyse lactose 26 present in the lactulose syrup, the hydrolysed sample was treated with activated charcoal 27 and water/ethanol solutions to eliminate all monosaccharides. The proposed method 28 offers a product with high purity $(>94 \%)$ and high recovery $(>80 \%)$ of lactulose.

Key words: lactulose, purification, enzymes, activated charcoal, $\beta$-galactosidases, prebiotic. 


\section{Introduction}

Lactulose, (4-O- $\beta$-D-galactopyranosyl-D-fructose), is a synthetic disaccharide which does not occur naturally and can be synthesized by both chemical and enzymatic methods [1-4]. The beneficial effects of lactulose in the human large intestine have been intensively studied for more than 60 years [3-5]. Lactulose is mainly used in medicine in the form of syrup or as a crystalline product for the symptomatic treatment of constipation and the treatment of portal systemic encephalopathy [6]. Although the use of lactulose as a food ingredient was introduced as far back as the 1950s by Petuely [7], with the growing interest in functional foods, the use of lactulose as prebiotic ingredient is increasing considerably as it offers excellent and scientifically tested functional properties and applications [3].

Lactulose can be chemically obtained by isomerization of lactose in basic media including calcium hydroxide, ammonia, sodium sulphite or tertiary amines [8-11]. These methods afford low yields and are tedious, the main difficulty being the purification of lactulose from the reaction mixture. Complexing agents like borate and aluminate increases the lactulose yield up to $70-80 \%$ but its removal from reaction mixtures increases the production costs [12].

The enzymatic synthesis of lactulose has been also produced using $\beta$ galactosidases from different sources and fructose as acceptor [13-17], as well as glucose isomerase [18] or cellobiose 2-epimerase [1-2].

52 Despite the numerous research studies addressing the enzymatic synthesis of lactulose, the industrial production is still mainly done by chemical isomerization [4-18]. Most of the lactulose syrups currently available on the market to be used in the 
pharmaceutical and food industries, contain $666 \mathrm{mg} / \mathrm{mL}$ lactulose, but also contain a relatively high percentage of other carbohydrates mainly lactose $(67 \mathrm{mg} / \mathrm{mL})$ and galactose $(67 \mathrm{mg} / \mathrm{mL})$ which increase the calorific value of the product. The presence of these carbohydrates may be problematic for therapies that require the administration of pure lactulose, for example, in patients suffering from diabetes, with galactosaemia or who require a diet without lactose. That is why there is an increasing need of a simple inexpensive lactulose purification process.

It is known that removal of lactose impurity from lactulose is a difficult task whereas monosaccharide impurities can be easily removed from lactulose by treatment with activated charcoal [19]. In a previous study on transglycosylation reactions of lactose and lactulose by $\beta$-galactosidase from Bacillus circulans [20] we observed different rates of hydrolysis for lactose and lactulose. Based on those results, this study is focused on the search for an efficient and affordable method to purify commercial lactulose syrups, using enzymes, to eliminate lactose and monosaccharides and reduce the presence of other carbohydrates and, thus, to extend the scope of lactulose applications. Here, we present a comparative study between four commercial $\beta$-galactosidases from Kluyveromyces lactis (Lactozym ${ }^{\circledR}$ Pure 6500 L), Aspergillus oryzae (Biolactase ${ }^{\circledR} \mathrm{F}$ CONC), Bacillus circulans (Biolactasa ${ }^{\circledR}$ NTL*2) and Bifidobacterium bifidum (Saphera ${ }^{\circledR}$ 2600 L) which were used as reaction catalysts. In addition, response surface methodology (RSM) has been used to optimize the selective enzymatic hydrolysis of lactose present in commercial lactulose. 


\section{Experimental}

\subsection{Materials and samples}

Eleven commercial lactulose syrups (Table 1) were purchased in seven different countries. The lactulose standard used to prepare the calibration curve was purchased from Sigma-Aldrich and had a purity degree greater than $95 \%$.

Four commercial $\beta$-galactosidases: Saphera ${ }^{\circledR} 2600$ L from Bifidobacterium bifidum, and Lactozym ${ }^{\circledR}$ Pure 6500 L from Kluyveromyces lactis, were purchased from Novozyme (Denmark); Biolactasa ${ }^{\circledR}$ NTL*2 from Bacillus circulans and Biolactase ${ }^{\circledR}$ F CONC from Aspergillus oryzae were purchased from Biocon (Spain).

Analytical standards of galactose, glucose, fructose, lactose, lactulose, raffinose, and phenyl- $\beta$-glucoside were acquired from Sigma-Aldrich (St Louis, MO). Activated charcoal (Darco G60) was purchased from J.T. Baker (Netherlands).

\subsection{Selective enzymatic hydrolysis of lactose present in lactulose syrup}

Lactose present in commercial lactulose syrup (sample number 3) was hydrolysed using $\beta$-galactosidases from Bifidobacterium bifidum (Saphera ${ }^{\circledR} 2600$ L), Kluyveromyces lactis (Lactozym ${ }^{\circledR}$ Pure 6500 L), Bacillus circulans (Biolactasa ${ }^{\circledR}$ NTL*2) and Aspergillus oryzae (Biolactase ${ }^{\circledR}$ F CONC). Lactose hydrolysis were conducted at the optimum $\mathrm{pH}$ and temperatures previously reported for the enzymatic preparation suppliers, i.e. pH 6.0 and $40^{\circ} \mathrm{C}$ for Saphera ${ }^{\circledR} 2600 \mathrm{~L}$; pH 6.5 and $50^{\circ} \mathrm{C}$ for Lactozym $^{\circledR}$ Pure $6500 \mathrm{~L}$ and Biolactasa ${ }^{\circledR}$ NTL*2 and $\mathrm{pH} 4.5$ and $50^{\circ} \mathrm{C}$ for Biolactase ${ }^{\circledR}$ F CONC. In order to evaluate the $\beta$-galactosidase selectivity, each enzyme $(3 \mathrm{U} / \mathrm{mL})$ was incubated with commercial lactulose syrup $(10 \% \mathrm{w} / \mathrm{v})$ at the optimal $\mathrm{pH}$ and temperatures for each enzyme. Aliquots 
were withdrawn at specific time intervals $(0,15,30,60,90,120,180$ and $240 \mathrm{~min})$ and immediately immersed in boiling water for $5 \mathrm{~min}$ to inactivate the enzyme and then stored at $-18{ }^{\circ} \mathrm{C}$ for subsequent analysis $(n=3)$. Those enzymes with selectivity to hydrolyse lactose but no lactulose were chosen to optimize the lactose hydrolysis methodology using Response Surface Methodology (RSM).

\subsection{Optimization of lactose hydrolysis conditions by RSM}

Lactose hydrolysis optimization, using the commercial lactulose preparation (sample number 3) was performed using a Central Composite Design (CCD) with three independent variables: lactulose concentration $\mathrm{X}_{1}(3.15-25 \% \mathrm{w} / \mathrm{w})$, enzymatic dose of two selected enzymes $\left(\right.$ Saphera ${ }^{\circledR}$ and Biolactasa ${ }^{\circledR}{ }^{\circledR}$ NTL $\left.* 2\right) \mathrm{X}_{2}(4.0-15.0 \mathrm{U} / \mathrm{mL})$ and time $\mathrm{X}_{3}$ (4.1- $\left.48 \mathrm{~h}\right)$. Three responses (dependent variables) were taken into account to optimise lactulose syrup purification by means of RSM: recovery $(\% \mathrm{w} / \mathrm{w})$ of lactulose, lactose and epilactose, for each enzyme. A total of 34 points (24 axial, 2 center and 8 factorial) for each selected enzyme were conducted. The obtained data were processed using statistical software package Design-Expert 10 (CAMO-ASA, Norway).

2.4. Fractionation of carbohydrates in selectively hydrolyzed lactulose syrups by activated charcoal

In order to remove monosaccharides, the selected hydrolysates of lactulose syrups were purified with activated charcoal following the methodology proposed by JulioGonzález et al. [19] with some modifications. Briefly, mixture reaction (500 mg) and activated charcoal $(6 \mathrm{~g})$ were added to $100 \mathrm{~mL}$ of ethanol $(1 \%, \mathrm{v} / \mathrm{v})$. The resulting mixture was stirred for $30 \mathrm{~min}$ at $25^{\circ} \mathrm{C}$, and then filtered through Whatman No.1 paper (Whatman International Ltd., Maidstone, UK) under vacuum (this process is named by the 
desorption step 1). The process was repeated for a second time to ensure removal of total monosaccharides (step 2). The remained lactulose in the washed charcoal was desorbed by adding $100 \mathrm{ml}$ of ethanol ( $8 \% \mathrm{v} / \mathrm{v})$ and stirring for $30 \mathrm{~min}$ at $25^{\circ} \mathrm{C}$, and then filtered through Whatman No.1 paper under vacuum (step 3); this process was done two more times (steps 4 and 5) to ensure removal of total disaccharides. Desorption of oligosaccharides from the washed activated charcoal was carried out by adding $100 \mathrm{~mL}$ of ethanol $(50 \%, \mathrm{v} / \mathrm{v})$ and stirring the mixture during $30 \mathrm{~min}$ and subsequent filtration (step 6).

\subsection{Gas chromatographic analysis of carbohydrates}

Mono- and disaccharides were analyzed by gas chromatography-flame ionisation detection (GC-FID) as trimethylsilylated ethers (TMSI) prepared following the method of Montilla et al. [21] with some modifications. The dried mixtures were treated with 100 $\mu \mathrm{l}$ of dimethylformamide (DMF) and heating at $70^{\circ} \mathrm{C}$ for $30 \mathrm{~min}$. To silylate the carbohydrates $150 \mu \mathrm{N}$-trimethylsilylimidazole were added; the reaction was completed in $30 \mathrm{~min}$ at $70{ }^{\circ} \mathrm{C}$. TMSI derivatives of carbohydrates were extracted with $600 \mu \mathrm{l}$ of hexane and $300 \mu \mathrm{l}$ of water. Separation of carbohydrates was carried out in an Agilent Technologies gas chromatograph (Mod 7890A) equipped with a flame ionization detector (FID) and a fused silica capillary column SPB-50, bonded, crosslinked phase $(50 \%$ phenyl-50\% methylpolysiloxane; $30 \mathrm{~m} \mathrm{x} 250 \mu \mathrm{m}$ id., $0.25 \mu \mathrm{m}$ film thickness) (SUPELCO, USA). The initial oven temperature was $200^{\circ} \mathrm{C}$ increasing to $230{ }^{\circ} \mathrm{C}$ at a rate of $4{ }^{\circ} \mathrm{C} / \mathrm{min}$, and finally increased to $250{ }^{\circ} \mathrm{C}$ at $1{ }^{\circ} \mathrm{C} / \mathrm{min}$. The temperature of injector and detector were at $280^{\circ} \mathrm{C}$ and $295^{\circ} \mathrm{C}$, respectively. Injections were carried out in split mode 

GC-FID of trimethylsilylated oximes (TMSO) derivatives prepared following the method of Brobst and Lott. [22]. Sugar oximes were formed by adding $250 \mu \mathrm{L}$ of hydroxylamine chloride $(2.5 \%)$ in pyridine to dried samples and heating the mixture at $70^{\circ} \mathrm{C}$ for $30 \mathrm{~min}$. Then, they were silylated with hexamethyldisilazane $(250 \mu \mathrm{L})$ and trifluoroacetic acid (25 $\mu \mathrm{L})$ at $50{ }^{\circ} \mathrm{C}$ for $30 \mathrm{~min}$. Reaction mixtures were centrifuged at $10,000 \mathrm{rpm}$ for $2 \mathrm{~min}$ at room temperature. Separation of carbohydrates was carried out in an Agilent Technologies gas chromatograph (Mod 7890A) equipped with a flame ionization detector (FID) and a fused silica capillary column DB-5HT (5\%-phenyl-methylpolysiloxane; 30m x $0.25 \mathrm{~mm} \times 0.10 \mu \mathrm{m})$ (Agilent). The oven temperature was initially set at $150{ }^{\circ} \mathrm{C}$ then increased at $3{ }^{\circ} \mathrm{C} / \mathrm{min}$ to $380{ }^{\circ} \mathrm{C}$. The injector and detector temperatures were set at 280 and $385^{\circ} \mathrm{C}$, respectively. Injections were carried out in split mode (1:20) using nitrogen at $1 \mathrm{~mL} / \mathrm{min}$ as the carrier gas [19].

Data acquisition and integration were performed using Agilent ChemStation Rev. B.03.01 software. To calculate the response factors relative to the internal standard, solutions containing glucose, galactose, lactose, lactulose and raffinose were prepared over the expected concentration range in samples. The identities of carbohydrates were confirmed by comparison with relative retention times (RRT) of standard samples.

167 Response factors were calculated after the duplicate analysis of standard solutions over the expected concentration range in samples. The amount of different carbohydrates was expressed as \% carbohydrates recovered and \% weight of the total carbohydrates content in the reaction mixtures. All analyses were carried out in duplicate and data were expressed as mean \pm standard deviation (SD). 

the statistical software package SPSS (SPSS Inc., IL, USA). The differences were considered significant when $\mathrm{P}<0.05$.

\section{Results and Discussion}

\subsection{Carbohydrate content in commercial lactulose preparations}

Fig. 1 (a) shows the chromatographic profile (GC-FID) of a commercial lactulose preparation. As can be observed, beside the main component, lactulose (labelled as peak disaccharides (lactose as peak 6 and epilactose as peak 4) were also detected. Table 1 shows the content of carbohydrates present in the different commercial samples analysed. Lactulose content (as indicated in the label) varies widely according to manufacturer although most of the samples (ten of the twelve samples) showed comparable lactulose content ranging from 60 to $67 \mathrm{~g} / 100 \mathrm{~mL}$, and only two samples showed lactulose contents of 35 and $59 \mathrm{~g} / 100 \mathrm{~mL}$ due to the presence of other ingredients such as simethicone or propilenglycol that were declared in the label of samples. Regarding carbohydrate composition, all samples showed similar values except one which showed the presence of small amounts of tagatose, isomer of galactose that could be originated from galactose by isomerization under basic conditions. These results suggest that all commercial lactulose samples were produced with similar manufacturing process. Although industrial production of lactulose is mainly achieved by chemical isomerization of lactose in basic media [8], lactulose can also be obtained by enzymatic transglycosylation when the hydrolysis of lactose by $\beta$-galactosidase takes place in presence of fructose [17]. The presence of epilactose in all analyzed samples is indicative of isomerization in basic 


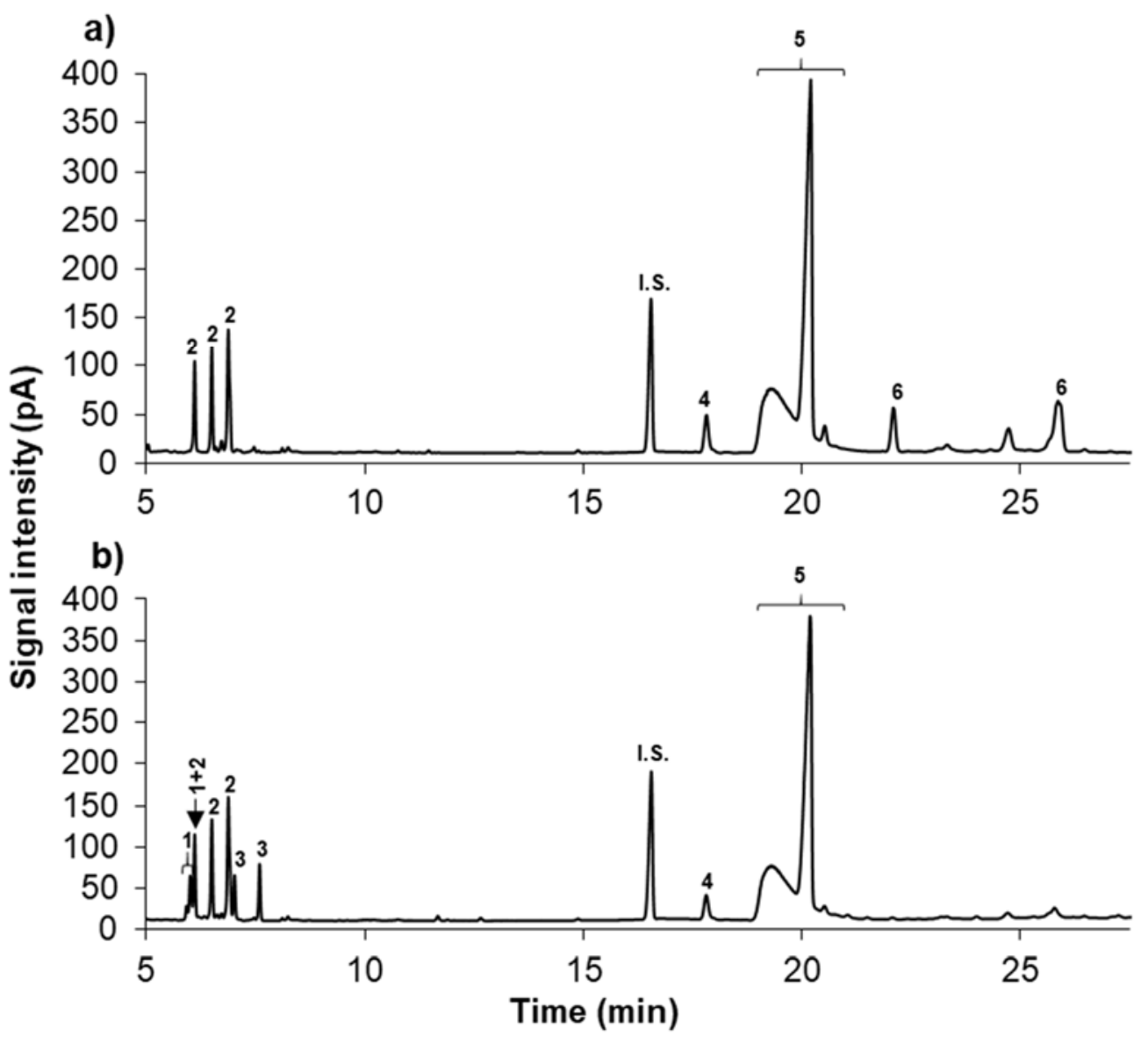

media since it is a secondary product formed during chemical isomerization of lactose [23].

98
200

201

202

203

205 204 (phenyl- $\beta$-glucoside).

Fig. 1. GC-FID chromatographic profiles of TMSI derivatives of carbohydrates present in a commercial lactulose syrup (sample number 3 in Table 1) before (a) and after (b) hydrolysis by Saphera ${ }^{\circledR} 2600 \mathrm{~L}, \beta$-galactosidase $(11 \mathrm{U} / \mathrm{mL})$ during 4.1 h. 1 : fructose; 2 :

Table 1. Content (g/100mL lactulose syrup) of monosaccharides (galactose and tagatose), lactose, lactulose and epilactose found in commercial lactulose preparations. 


\begin{tabular}{|c|c|c|c|c|c|c|}
\hline \multirow{2}{*}{ Sample } & \multirow{2}{*}{$\begin{array}{l}\text { Country of } \\
\text { origin }\end{array}$} & \multicolumn{5}{|c|}{ Carbohydrate content (g/100mL of lactulose syrup) } \\
\hline & & Lactulose & Tagatose & Galactose & Lactose & Epilactose \\
\hline 1 & Russia & $68.3 \pm 5.9$ & - & $6.8 \pm 0.2$ & $4.5 \pm 0.1$ & $4.2 \pm 0.2$ \\
\hline 2 & Germany & $66.6 \pm 3.8$ & - & $6.6 \pm 0.8$ & $4.3 \pm 0.1$ & $4.2 \pm 0.1$ \\
\hline 3 & Spain & $66.3 \pm 2.0$ & - & $7.2 \pm 0.3$ & $4.7 \pm 0.1$ & $3.8 \pm 0.1$ \\
\hline 4 & Italy & $65.7 \pm 1.2$ & - & $6.0 \pm 0.1$ & $3.7 \pm 0.1$ & $3.7 \pm 0.0$ \\
\hline 5 & Russia & $65.6 \pm 1.5$ & - & $6.2 \pm 0.0$ & $4.3 \pm 0.4$ & $4.7 \pm 1.1$ \\
\hline 6 & Spain & $64.6 \pm 3.8$ & $0.62 \pm 0.0$ & $5.6 \pm 0.1$ & $4.5 \pm 0.2$ & $2.3 \pm 0.0$ \\
\hline 7 & Canada & $63.5 \pm 0.5$ & - & $6.5 \pm 0.0$ & $4.3 \pm 0.0$ & $3.6 \pm 0.0$ \\
\hline 8 & Spain & $63.3 \pm 0.0$ & - & $5.5 \pm 0.0$ & $3.6 \pm 0.0$ & $3.6 \pm 0.0$ \\
\hline 9 & Russia & $61.7 \pm 0.8$ & - & $5.6 \pm 0.6$ & $3.5 \pm 0.1$ & $3.5 \pm 0.2$ \\
\hline 10 & Netherlands & $60.2 \pm 0.3$ & - & $6.2 \pm 0.6$ & $4.7 \pm 0.1$ & $4.4 \pm 0.1$ \\
\hline 11 & Colombia & $58.9 \pm 4.5$ & - & $7.4 \pm 0.2$ & $4.4 \pm 0.1$ & $4.2 \pm 0.2$ \\
\hline 12 & Russia & $35.2 \pm 6.5$ & - & $3.4 \pm 0.4$ & $2.3 \pm 0.1$ & $2.2 \pm 0.3$ \\
\hline
\end{tabular}

209

210 Standard deviation $(n=2)$

211

212 3.2. Selectivity of $\beta$-galactosidases to hydrolyze lactose present in commercial lactulose

213 syrups.

214 Since the removal of lactose and epilactose from lactulose is not economically

215 feasible, the previous hydrolysis of both compounds is required. However, since lactulose

216 and epilactose are also substrates for microbial $\beta$-galactosidases, the selective hydrolysis

217 of lactose and epilactose in the presence of large amounts of lactulose has to be optimized.

In order to choose the right enzyme that better leads to the selective hydrolysis of

219 disaccharides other than lactulose, four different commercial enzyme preparations were

tested. Fig. 2 shows the evolution of content of lactose, lactulose and epilactose during 
223 (Biolactasa ${ }^{\circledR}$ NTL $^{*}$ ) (Fig. 2 c) and Bifidobacterium bifidum (Saphera ${ }^{\circledR} 2600$ L) (Fig. 2

224 d) preferentially hydrolyzed lactose and epilactose over lactulose whereas Lactozym ${ }^{\circledR}$ 225 Pure 6500 L from Kluyveromyces lactis and Biolactase ${ }^{\circledR}$ F CONC from Aspergillus oryzae hydrolyzed lactulose and lactose at similar rates, as can be observed in Fig. 2 a

227 and $\mathbf{2} \mathbf{b}$. Therefore, these two last enzymes were discarded for the optimization of lactose hydrolysis methodology by RSM. 


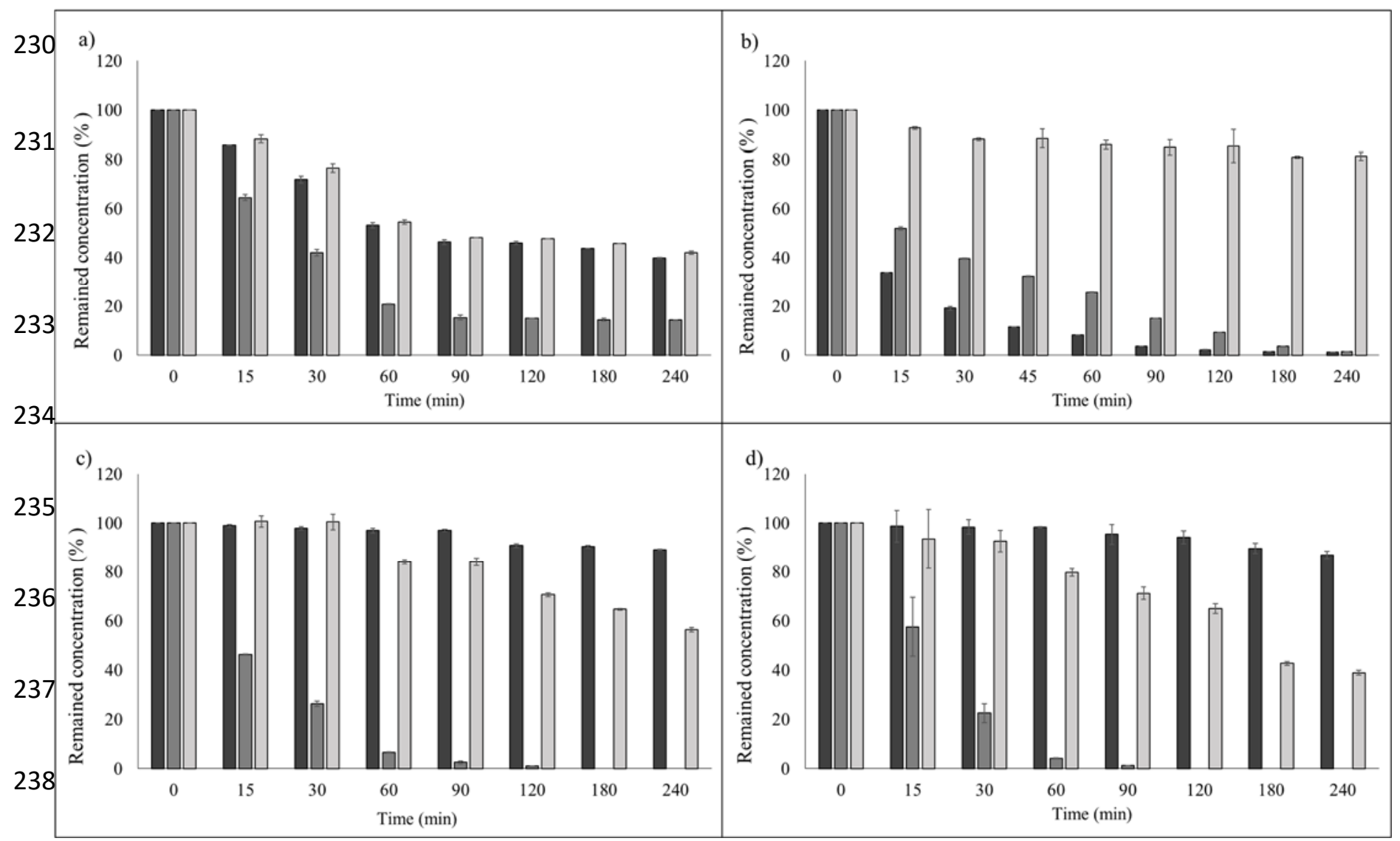

239

240 Fig. 2. Remained concentration (\%) of lactulose $\square$, lactose $\square$, and epilactose $\square$ found 241 during hydrolysis for 240 minutes, of commercial lactulose syrup (10\% w/v) (sample 242 number 3 in Table 1) by four commercial $\beta$-galactosidases preparations $(3 \mathrm{U} / \mathrm{mL})$. a) 243 Lactozym $^{\circledR}$ Pure 6500 L Kluyveromyces lactis ( $\mathrm{pH} 6.5$ and $50{ }^{\circ} \mathrm{C}$ ); b) Biolactase ${ }^{\circledR} \mathrm{F}$ 244 CONC Aspergillus oryzae (pH 4.5 and $\left.50{ }^{\circ} \mathrm{C}\right)$; c) Biolactasa ${ }^{\circledR}$ NTL*2 Bacillus circulans 245 (pH 6.5 and $50{ }^{\circ} \mathrm{C}$ ); d) Saphera ${ }^{\circledR} 2600$ L Bifidobacterium bifidum (pH 6 and $40{ }^{\circ} \mathrm{C}$ ).

3.3 Optimization of lactose hydrolysis by RSM

The independent variables and experimental responses are shown in Table 2. The

250 experimental data was fitted with the CCD model as shown in Equation 1 (Saphera ${ }^{\circledR} 2600$ 
254 the two $\beta$-galactosidases under study (Saphera ${ }^{\circledR} 2600 \mathrm{~L}$ and Biolactasa ${ }^{\circledR}$ NTL*2), with the exception of lactose recovery responses for both enzymatic preparations and epilactose recovery responses for Biolactasa ${ }^{\circledR}$ NTL $* 2$ for which there is a significant lack of fit $(\mathrm{p}<0.0001)$.

Equation 1 (Saphera ${ }^{\circledR} 2600$ L):

Lactulose recovery $(\%)=100.8+2.5 \mathrm{X}_{1}-7.1 \mathrm{X}_{2}-2.9 \mathrm{X}_{3}-0.02 \mathrm{X}_{1}^{2}+0.17 \mathrm{X}_{2}^{2}+0.03$ $\mathrm{X}_{3}{ }^{2}$

\section{Equation 2 (Biolactasa ${ }^{\circledR}$ NTL*2)}

Lactulose recovery $(\%)=106.1+2.9 \mathrm{X}_{1}-8.9 \mathrm{X}_{2}-2.5 \mathrm{X}_{3}+0.03 \mathrm{X}_{1} * \mathrm{X}_{2}-0.03 \mathrm{X}_{1}^{2}+$ $0.17 \mathrm{X}_{2}^{2}+0.02 \mathrm{X}_{3}^{2}$

Table 3 shows the optimal operation conditions and the theoretical responses values, calculated by the polynomial equation and the validated model. In order to validate these optimal conditions, confirmation experiments were carried out and the results obtained were compared with the theoretical results (Table 3). The aim of the numerical range optimization is to operate in conditions with the higher lactulose recovery where lactose is completely hydrolyzed (Scenario 1 - Table 3) or where lactose and epilactose are completely hydrolyzed (Scenario 2 - Table 3). The lactulose recovery (\%) values were in the prediction interval, which is wider than the confidence interval (95\%) since the model includes the sampling bias. Therefore, sample number 1

Table 2. Central Composit Design (CCD) runs. Independent variables and experimental response found during hydrolysis of lactose and epilactose present in commercial lactulose syrup using Saphera ${ }^{\circledR} 2600$ L or Biolactasa ${ }^{\circledR}$ NTL*2 $\beta$-galactosidases. 


\begin{tabular}{|c|c|c|c|c|c|c|c|c|c|}
\hline \multirow{2}{*}{$\underset{\mathbf{n}}{\mathbf{R u}}$} & \multirow{2}{*}{$\begin{array}{c}\text { Lactulos } \\
\text { e (\% } \\
\text { w/v) } \\
\mathrm{X}_{1} \\
\end{array}$} & \multirow{2}{*}{$\begin{array}{c}\text { Enzymati } \\
\text { c activity } \\
(\mathrm{U} / \mathrm{mL}) \\
\mathrm{X}_{2} \\
\end{array}$} & \multirow{2}{*}{$\begin{array}{c}\text { Time } \\
\text { (h) } \\
\text { X3 }\end{array}$} & \multicolumn{3}{|c|}{$\begin{array}{c}\text { Recovery (\%) (Saphera }{ }^{\circledR} 2600 \\
\text { L) }\end{array}$} & \multicolumn{3}{|c|}{$\begin{array}{c}\text { Recovery (\%) (Biolactasa } \\
\text { NTL*2) } \\
\end{array}$} \\
\hline & & & & Lactulose & Lactose & Epilactose & Lactulose & Lactose & Epilactose \\
\hline 1 & 13.15 & 15 & 24.2 & 30.5 & 0 & 0 & 31.2 & 0 & 0 \\
\hline 2 & 3.15 & 4 & 4.1 & 78.1 & 0 & 24 & 87.1 & 0 & 37.8 \\
\hline 3 & 13.15 & 3 & 24.2 & 84.8 & 0 & 32.3 & 92.5 & 3.5 & 46.5 \\
\hline 4 & 25 & 9 & 24.2 & 70.3 & 0 & 21.1 & 72.9 & 3.3 & 31.9 \\
\hline 5 & 13.15 & 9 & 0.3 & 103.3 & 37.2 & 88.3 & 97 & 55.5 & 89.2 \\
\hline 6 & 25 & 9 & 24.2 & 67.7 & 0 & 20.5 & 72.7 & 3.9 & 30.4 \\
\hline 7 & 13.15 & 15 & 24.2 & 30.5 & 0 & 0 & 32.8 & 0 & 0 \\
\hline 8 & 23.1 & 14 & 4.1 & 89.1 & 0 & 54.4 & 90.1 & 0 & 63.8 \\
\hline 9 & 3.15 & 4 & 44.2 & 27.6 & 0 & 0 & 24 & 0 & 0 \\
\hline 10 & 13.15 & 9 & 0.3 & 96.4 & 34.3 & 83 & 100.3 & 59.8 & 97.5 \\
\hline 11 & 13.15 & 3 & 24.2 & 79.6 & 0 & 26.4 & 93.5 & 3.6 & 52.9 \\
\hline 12 & 13.15 & 9 & 48 & 37.6 & 0 & 0 & 36.1 & 0 & 0 \\
\hline 13 & 13.15 & 9 & 48 & 37.2 & 0 & 0 & 37.5 & 0 & 0 \\
\hline 14 & 13.15 & 9 & 24.2 & 54.1 & 0 & 5.1 & 54.9 & 0 & 4.6 \\
\hline 15 & 13.15 & 9 & 48 & 29.5 & 0 & 0 & 46.1 & 0 & 0 \\
\hline 16 & 13.15 & 9 & 0.3 & 97.8 & 37 & 82.3 & 103.2 & 54.8 & 95.6 \\
\hline 17 & 13.15 & 9 & 24.2 & 54.7 & 0 & 4.3 & 52.3 & 0 & 5.1 \\
\hline 18 & 13.15 & 15 & 24.2 & 30.5 & 0 & 0 & 30.8 & 0 & 0 \\
\hline 19 & 13.15 & 9 & 48 & 30.9 & 0 & 0 & 34.1 & 0 & 0 \\
\hline 20 & 25 & 9 & 24.2 & 63.4 & 0 & 16.7 & 66.9 & 3.4 & 29.3 \\
\hline 21 & 13.15 & 15 & 24.2 & 28.5 & 0 & 0 & 31.9 & 0 & 0 \\
\hline 22 & 1.25 & 9 & 24.2 & 0.8 & 0 & 0 & 0.9 & 0 & 0 \\
\hline 23 & 1.25 & 9 & 24.2 & 7.5 & 0 & 0 & 0.4 & 0 & 0 \\
\hline 24 & 1.25 & 9 & 24.2 & 6 & 0 & 0 & 1 & 0 & 0 \\
\hline 25 & 13.15 & 3 & 24.2 & 75 & 0 & 25.6 & 89.8 & 2.9 & 40.1 \\
\hline 26 & 23.1 & 4 & 44.2 & 77.3 & 0 & 28.3 & 79.2 & 0 & 44 \\
\hline 27 & 23.1 & 14 & 44.2 & 38.7 & 0 & 0 & 33.5 & 0 & 0 \\
\hline 28 & 13.15 & 9 & 0.3 & 99.7 & 30.9 & 84.1 & 98.2 & 52.6 & 88.4 \\
\hline 29 & 25 & 9 & 24.2 & 68.9 & 0 & 16.9 & 74.4 & 3.5 & 30.8 \\
\hline 30 & 13.15 & 3 & 24.2 & 78.2 & 0 & 25.3 & 87.4 & 3.3 & 40 \\
\hline 31 & 3.15 & 14 & 4.1 & 42.4 & 0 & 0 & 55.5 & 0 & 0 \\
\hline 32 & 23.1 & 4 & 4.1 & 97 & 10.6 & 87.3 & 95.4 & 0 & 81.6 \\
\hline 33 & 3.15 & 14 & 44.2 & 0.2 & 0 & 0 & 0 & 0 & 0 \\
\hline 34 & 1.25 & 9 & 24.2 & 2.2 & 0 & 0 & 0 & 0 & 0 \\
\hline
\end{tabular}


Table 3. Optimal operation conditions, predicted and experimental response for lactulose recovery, obtained from hydrolysis of commercial lactulose syrup using Saphera ${ }^{\circledR} 2600$

\begin{tabular}{|c|c|c|c|c|c|c|c|}
\hline \multirow[t]{2}{*}{$\beta$-Galactosidases } & \multirow[t]{2}{*}{ Scenario } & \multirow{2}{*}{$\begin{array}{c}\text { Lactulose } \\
(\% \text { w/v })\end{array}$} & \multirow{2}{*}{$\begin{array}{c}\text { Enzymatic } \\
\text { activity } \\
(\mathrm{U} / \mathrm{mL})\end{array}$} & \multirow{2}{*}{$\begin{array}{c}\text { Time } \\
\text { (h) }\end{array}$} & \multicolumn{2}{|c|}{$\begin{array}{l}\text { Lactulose } \\
\text { recovery } \\
(\%)\end{array}$} & \multirow{2}{*}{$\begin{array}{c}\begin{array}{c}\text { Epilactose } \\
\text { recovery } \\
(\%)\end{array} \\
\text { Experimental } \\
\text { Mean }(n=4)\end{array}$} \\
\hline & & & & & $\begin{array}{l}\text { Predicted } \\
\text { Mean }\end{array}$ & $\begin{array}{c}\text { Experimental } \\
\text { Mean }(n=4)\end{array}$ & \\
\hline \multirow{2}{*}{ Saphera ${ }^{\circledR} 2600 \mathrm{~L}$} & 1 & 21.0 & 11 & 4.1 & $96.9 \pm 3.5$ & $95.2 \pm 3.3$ & $79.0 \pm 2.4$ \\
\hline & 2 & 21.8 & 11.5 & 38.5 & $44.33 \pm 3.5$ & $48.2 \pm 1.4$ & $0.0 \pm 0.0$ \\
\hline \multirow{2}{*}{ Biolactasa NTL $* 2$} & 1 & 21.9 & 11.4 & 4.1 & $90.2 \pm 3.5$ & $89.8 \pm 2.0$ & $71.3 \pm 2.6$ \\
\hline & 2 & 23.1 & 13.4 & 26.7 & $51.8 \pm 3.5$ & $52.0 \pm 1.2$ & $11.3 \pm 0.9$ \\
\hline
\end{tabular}

SD: Standard deviation

Scenario 1: Maximize initial lactulose content and lactulose recovery; keep in working range enzymatic activity and time; complete hydrolysis of lactose

Scenario 2: Maximize initial lactulose content and lactulose recovery; keep in working range enzymatic activity and time; complete hydrolysis of lactose and epilactose.

containing $21 \%$ of lactulose and hydrolysed during $4.1 \mathrm{~h}$ with Saphera ${ }^{\circledR} 2600 \mathrm{~L} \beta$ galactosidase was selected for subsequent activate charcoal treatment to remove monosaccharides. In Fig. 1b can be observed a GC-profile of carbohydrates found in this sample, being fructose (peak 1), galactose (peak 2), glucose (peak 3), epilactose (peak 4) and lactulose (peak 5). cause the formation of oligosaccharides via transglycosylation, the time required in this study for complete hydrolysis of lactose was too short to lead to the synthesis of GOS in significant amounts. 


\subsection{Removal of monosaccharides by activated charcoal treatment}

Once selected the best enzymatic conditions to selectively hydrolyse lactose present in the lactulose syrup, the hydrolysed sample mixture (above mentioned) was treated with activated charcoal to eliminate all monosaccharides present in these hydrolysates. Table 4 shows the fractionation of carbohydrates using different water/ethanol solutions. Recovery of purified lactulose was performed in 5 steps applying different water/ethanol solutions $(1 / 99 ; 8 / 92 ; \mathrm{v} / \mathrm{v}$; five steps $)$. The removal of monosaccharides was mainly achieved during the first step using $1 \%$ ethanol but a second step under the same conditions was required for their complete removal. Once total monosaccharides were removed high purity lactulose was recovered during the third to fifth steps using $8 \%$ ethanol. Through these three steps, $80.3 \%$ of total lactulose was recovered with a purity of, at least, $94.2 \%$, the rest being mainly epilactose $(3.7 \%)$ and other disaccharides (1.2\%). The remaining oligosaccharides adsorbed on the activated charcoal were desorbed during the sixth step using 50/50 water/ ethanol solution. Epilactose, present in the purified lactulose in amounts lower than $4 \%$, may contribute to its prebiotic activity since it is considered a potential prebiotic disaccharide [24].

\section{Conclusions}

These results are the first reported in the literature dealing with the purification of commercial lactulose syrup by removing lactose and monosaccharides using a sequential methodology which involves the selective hydrolysis of lactose by commercial $\beta$ galactosidases followed by adsorption of carbohydrates on activated charcoal, removal of monosaccharides and recovery of lactulose using different proportions of water/ethanol solutions. Lactulose recovery was of $80.3 \%$ with a purity of $94 \%$. The resulting product 
Amount of desorbed carbohydrates (mg/g of hydrolyzed lactulose syrup)*

\begin{tabular}{ccc}
\hline $\begin{array}{c}\text { Desorption } \\
\text { step }\end{array}$ & $\begin{array}{c}\text { Ethanol/water } \\
\text { mixtures }\end{array}$ & $\begin{array}{c}\text { Amount of desorbed carbohydrates } \\
(\mathrm{mg} / \mathrm{g} \text { of hydrolyzed lactulose syrup)* }\end{array}$
\end{tabular}

Fructose Galactose Glucose Lactulose Epilactose $\begin{gathered}\text { Other } \\ \text { disaccharides }\end{gathered}$ Trisaccharides

\begin{tabular}{ccccccccc}
\hline 1 & $1 / 99$ & $7.9 \pm 0.1$ & $48.5 \pm 0.2$ & $15.9 \pm 0.1$ & $25.3 \pm 1.3$ & $0.5 \pm 0.0$ & $0.2 \pm 0.0$ & $0.2 \pm 0.0$ \\
2 & $1 / 99$ & $0.2 \pm 0.1$ & $6.0 \pm 0.3$ & $1.8 \pm 0.0$ & $28.9 \pm 0.9$ & $0.4 \pm 0.0$ & $0.1 \pm 0.1$ & $0.1 \pm 0.1$ \\
3 & $8 / 92$ & $0.0 \pm 0.0$ & $0.0 \pm 0.0$ & $0.0 \pm 0.0$ & $338.1 \pm 9.5$ & $11.3 \pm 0.2$ & $4.3 \pm 0.1$ & $2.6 \pm 0.1$ \\
4 & $8 / 92$ & $0.0 \pm 0.0$ & $0.0 \pm 0.0$ & $0.0 \pm 0.0$ & $58.1 \pm 3.8$ & $3.7 \pm 0.3$ & $0.9 \pm 0.1$ & $0.6 \pm 0.1$ \\
5 & $8 / 92$ & $0.0 \pm 0.0$ & $0.0 \pm 0.0$ & $0.0 \pm 0.0$ & $11.4 \pm 1.0$ & $1.1 \pm 0.3$ & $0.2 \pm 0.1$ & $0.2 \pm 0.1$ \\
6 & $50 / 50$ & $0.0 \pm 0.0$ & $0.0 \pm 0.0$ & $0.0 \pm 0.0$ & $5.3 \pm 0.6$ & $0.6 \pm 0.1$ & $0.3 \pm 0.0$ & $0.3 \pm 0.0$ \\
\hline
\end{tabular}

332 Standard deviation $(\mathrm{n}=2)$

334 * Carbohydrate composition (mg/g of hydrolyzed lactulose syrup): Fructose 9.6 \pm 0.2 ; Galactose $66.2 \pm 1.8$; Glucose 20.8 \pm 0.3 ;

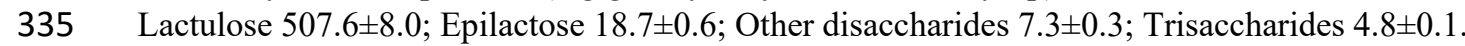

\section{Acknowledgements}


governorship of Bolivar-Colombia and CeiBA Foundation for the scholarship granted in the project "Bolívar Gana con Ciencia".

342

\section{REFERENCES}

[1] Y. S. Kim, D. K. Oh.Lactulose production from lactose as a single substrate

by a thermostable cellobiose 2-epimerase from Caldicellulosiruptor saccharolyticus.

Bioresour. Technol 104 (2012) 668-672.

347

[2] Y. S. Kim, J. E. Kim, D. K. Oh. Borate enhances the production of lactulose

from lactose by cellobiose 2-epimerase from Caldicellulosiruptor saccharolyticus. Bioresour. Technol 128 (2013) 809-812. (2009) 1987-1990.

[4] A. B. Sitanggang, A. Drews, M. Kraume. Recent advances on prebiotic lactulose production. World J. Microbiol. Biotechnol. 32 (2016) 154 (1-9).

[5] A. Mendez, A. Olano, A. Lactulose. A review of some chemical properties and applications in infant nutrition. Dairy Sci. Abstr. 41 (1979) 351-355.

[6] M. K. Bothe, A. J. H. Maathuis, S. Bellmann, J. M. B. M. van der Vossen, D. Dose-dependent prebiotic effect of lactulose in a computer-controlled in vitro model of the human large intestine. Nutrients 9 (2017) 767, (1-14). bifidogenic substances (bifidus factor). Z. Kinderheilkd 79 (1957) 174-179. 
[8] E. M. Montgomery, C. S. Hudson. Relations between rotatory power and structure

in the sugar group. XXVII. Synthesis of a new disaccharide ketose (lactulose) from lactose. J. Amer. Chem. Soc. 52 (1930) 2101-2106.

[9] W. M. Corbett, J. Kenner. The degradation of carbohydrates by alkali. 2 Lactose .J. Chem. Soc. 52 (1953) 2245-2247.

[10] K. B.Hicks, F. W. Parrish. A new method for the preparation of lactulose from lactose. Carbohydr. Res. 82 (1980) 393-397.

[11] M. Aider, D.de Halleux. Isomerization of lactose and lactulose production review. Trends Food Sci. Technol. 18 (2007) 356-364.

[12] M. J.Playne, R. G.Crittenden. Galacto-oligosaccharides and others products derived from lactose. In lactose, water, salts and minor constituents: Advanced Dairy Chemistry; McSweeney PLH, Fox PF, Eds.; Springer: New York, N.Y. 2009; Vol. 3, pp 121-201.

[13] V. Marja, V. Kauppinen. The formation of lactulose (4-O- $\beta$ galactopyranosylfructose) by $\quad \beta$-galactosidase. Acta Pharm. Fenn. 87 (1978) 75-83.

[14] Y. J. Lee, C. S. Kim, D. K. Oh. Lactulose production by $\beta$-galactosidases in impermeabilized cells of Kluyveromyces lactis. Appl. Microbiol. Biotechnol. 64 (2004) 787-793.

[15] J. Mayer, J. Conrad, I.Klaiber, S. Lutz-Wahl, U. Beifuss, L. Fischer. Enzymatic production and complete nuclear magnetic resonance assignment of the sugar lactulose. J. Agric. Food Chem. 52 (2004) 6983-6990.

[16] Y. S. Kim, C. S. Park, D. K. Oh. Lactulose production from lactose and fructose by a thermostable $\beta$-galactosidase from Sulfolobus solfataricus. Enzyme Microb. Technol. 39 (2006) 903-908. 
385

386

387

388

389

390

391

392

393

394

395

396

397

398

399

400

401

402

403

404

and lactulose using commercial $\beta$-galactosidase from Kluyveromyces lactis in the presence of fructose. Food Chem. 137 (2013) 137, 1-7.

[18] K. Wang, Y. Lu, W. Q. Liang, S. D. Wang, Y. Jiang, R. Huang, Y. H. Liu. Enzymatic synthesis of galacto-oligosaccharides in an organic-aqueous biphasic system by a novel $\beta$-galactosidase from a metagenomic library. J. Agric. Food Chem. 60 (2012) 3940-3946.

[19] C. Julio-González, L. Ruiz, N. Corzo, A. Olano, A. Purification of lactulose derived galactooligosaccharides from enzymatic reaction mixtures. Int. Dairy J. 85 (2018) 79-85.

[20] C. Sabater, A. Olano, M. Prodanov, A. Montilla, N. Corzo. An efficient process for obtaining prebiotic oligosaccharides derived from lactulose using isomerized and purified whey permeate. J Sci. Food Agric. 97 (2017) 5074-5082.

[21] A. Montilla, M. D. del Castillo, M. L. Sanz, A. Olano. Egg shell as catalyst of lactose isomerisation to lactulose. Food Chem. 90 (2005) 883-890.

[22] K. M. Brobst, C. E. Lott. Determination of some components in corn syrup by gas-liquid chromatography of trimethylsilyl derivatives. Cereal Chem. 43 (1966) 3543.

[23] A. Olano, I. Martinez-Castro. Formation of lactulose and epilactose from lactose in basic media. Milchwissenschaft 36 (1981) 533-536.

[24] J. Watanabe, M. Nishimukai, H. Taguchi, T. Senoura, S. Hamada, H. Matsui, T. Yamamoto, J. Wasaki, H. Hara, S. Ito. Prebiotic Properties of Epilactose, J. Dairy Sci. $91(2008) 4518-4526$. 